\title{
Sanctuary Says
}

ABSTRACT: In 2018, the New School Working Group on Expanded Sanctuary collaboratively organized a series of workshops in New York to reflect on the question of sanctuary as a conceptual and practical starting point for cross-coalitional politics, including its tensions and risks. This short piece is an attempt to bring together the sentiments expressed in those workshops by activists, organizers, students and academics focusing on anti-racist, pro-migrant, and pro-Indigenous struggles, in a form that engages sanctuary as an ongoing question.

KEYWORDS: abolition, accompaniment, community, expanded sanctuary, freedom cities, hospitality, political imagination, restorative justice

\section{What Is Sanctuary?}

In 2018, the New School Working Group on Expanded Sanctuary collaboratively organized a series of workshops in New York to reflect on this question. The workshops brought together activists, organizers, students and academics whose work spans anti-racist, pro-migrant, and pro-Indigenous struggles. Together, we reflected on sanctuary as a conceptual and practical starting point for cross-coalitional politics, including the tensions and risks of such a project.

This short piece is an attempt to assemble the sentiments expressed in those workshops in a form that engages sanctuary as an ongoing question. Our conception of sanctuary is not a consensus vision. It reflects the productive tension between the worlds we inhabit, the visions of justice we hold, and the solidarities we share. For example, the term "community defense" registered very differently for participants in different contexts. While some understood themselves to be working for progressive notions of community defense, others wanted to distance themselves from the term's deployment as part of right-wing and exclusionary practices. An expansive conception of sanctuary is not limited to conventional associations or historical meanings. Sanctuary entails a way of being as well as sets of principles, practices, affects, and risks. It is at once a political horizon, an already existing reality, and site of contention and risk. For many at the workshops, it was a term that simultaneously evoked promise, disappointment and betrayal, insofar as people felt it had been hijacked by city and state governments who have not honored its more radical commitments. We hope this reflective text will be read as a contingent collaboration-a provocation to open conversations, actions, and connections across communities, struggles, and continents. 
The text was compiled by The New School Working Group on Expanded Sanctuary, drawing on the discussions, notes, and sketches from the long table workshops: Individuals from the following organizations participated in the workshops.

New Sanctuary Coalition of New York

Otros Dreams en Acción (ODA)

Watch the Med Alarm Phone

Asamblea Popular de Familias Migrantes (APOFAM)

Red de Pueblos Transnacionales

New Sanctuary Movement of Philadelphia

Radio Progreso y Equipo de Reflexión, Investigación y Comunicación (ERIC), Honduras

Sanctuary Health, Vancouver

Yo Sí Sanidad Universal, Madrid

Mijente

Audre Lorde Project

Black Youth Project 100

NYU Dream

Make the Road New York

The New School Sanctuary Working Group

Hemispheric Institute, NYU

Undocublack Network

African Communities Together

Enlace

New York State Youth Leadership Council

National Immigration Law Center

Social Justice Institute of the Barnard Center for Research on Women

North Star Fund 
Sanctuary Strives for ...

Radical hospitality

Community defense

Civil disobedience

Civil initiative

Restorative justice

Web of resistance

Open borders

The commons

Revolutionary commitment

Uniting struggles

Radical education

Abolition as praxis

Holding difference

Defying norms

Working outside the state

The practice of community

Liberation

Freedom of Movement
Sanctuary Is ...

An experiment

Training for the not-yet

Taken, not given

A threshold

An interruption

A corridor

Imagination

Healing

Autonomy

Refuge

Presence

Solidarity

Courage

Dignity

Non-innocent

Shared fate

A call for equality

Care

Love

Always incomplete
Sanctuary Risks

Becoming ...

Humanitarianism

Charity

Paternalism

Defensiveness

Containment

Confinement

Limiting

A Fortress

A Prison

Compiled by Alexandra Délano Alonso, Abou Farman, Anne McNevin, Miriam Ticktin 